\title{
Awareness About Dental Radiography Among Dental Students
}

\author{
Rooha Sultan ${ }^{1} \quad$ BDS, \\ Khurram Parvez ${ }^{2} \quad$ BDS, MDS \\ Hina Qureshi $^{3} \quad$ FCPS, MCPS, MBBS
}

OBJECTIVE: To assess the difference in knowledge and attitude of graduates and undergraduates towards radiological practice and hazards in dentistry.

METHODOLOGY: A cross-sectional questionnaire based study was conducted on the dental students and trainees of a public sector teaching and tertiary care institute. Questionnaire consisted of three sections of multiple choice questions including those of knowledge about dental radiography (05 questions), attitude towards dental radiography (05 questions) and practices pertinent to dental radiography (06 questions). Statistical analysis was performed using SPSS version 16.0 software. Pearson's Chi Square test was used for the comparison of responses between the two groups at a $\mathrm{p}=$ value $<0.05$. RESULTS: Out of total 900 participants, data of 480 participants were included in the data analysis (postgraduates $=251$; undergraduates=229). Descriptive analysis shows that undergraduates had less knowledge and lack attitude and practices towards dental radiography as compared to postgraduate students with significant difference between the two groups ( $p$ $<0.05)$.

CONCLUSION: This lack of knowledge, attitude and practices among undergraduate students (including house officers) suggest that there is a need to improve the knowledge, attitudes and practices pertinent to basic dental radiography among undergraduate students and house officers and bring it at par to that of postgraduate trainees.

KEY WORDS: Radiography, graduates, undergraduates, protection, hazards, x-rays.

HOW TO CITE: Sultan R, Parvez K, Qureshi H. Awareness about dental radiography among dental students. J Pak Dent Assoc 2018;27(3):147-51.

DOI: https://doi.org/10.25301/JPDA.273.147

Received: 01 February 2018, Accepted: 16 April 2018

\section{INTRODUCTION}

X -rays are radiations of electromagnetic nature that produce ions on passing through matter that might pose injurious to healthy tissues. Production of free radicals or ions is alleged to have damaging effects to the human DNA by alteration and mutations. ${ }^{1-3}$ Apart from the negative effects the effectiveness of $x$-rays in dental imaging for diagnostic and clinical applications is far too valuable to be negated. ${ }^{1,4}$

Biological hazards associated with radiations are divided into stochastic and non-stochastic effects. Non-stochastic or deterministic effects are manifested only after a certain specified value of radiation dosage through exposure is breached while stochastic effects have no such threshold

1. Department of Science of Dental Materials, Dr Ishrat ul Ebad Khan Institute of Oral Health Sciences Dow University of Health Sciences, Karachi.

2. Department of Science of Dental Materials, Dr Ishrat ul Ebad Khan Institute of Oral Health Sciences Dow University of Health Sciences, Karachi.

3. Dr Sulaiman Al Habib Medical Group (HMG) Assuwaidi Riyadh, SA. Corresponding author: "Dr. Rooha Sultan" < rooha.sultan@duhs.edu.pk > value thus may be regarded as more detrimental and difficult to manage. High consideration is required by practitioners while advising $\mathrm{x}$-rays because radiations used in dentistry come under the category of stochastic effects. ${ }^{2,5,6}$ International Commission on Radiological Protection introduced its recommendations along with the ALARA principle 'As Low As Reasonably Achievable' in order to minimize patient as well as practitioner's exposure to unnecessary radiations. It also emphasizes on the protection protocol consisting of the technique related precautions such as of the ideal distance between the practitioner and the radiation source, use of dosimeter, $x$-ray film holding technique and the use of lead barriers. ${ }^{2,4,5,7}$

The KAP study conducted in January 2017 in Bihar, India revealed a low to average result among undergraduates and graduates regarding radiation biology and protection. ${ }^{1}$ The following study was conducted so that it may help us in evaluating the level of knowledge regarding radiological practices that undergraduate and graduates dental practitioners in our set up possess. 


\section{METHODOLOGY}

A cross-sectional questionnaire based study was carried out at Dow University of Health Sciences. All dental students and trainees including undergraduates, house officers and post graduate trainees enrolled in various programs of Dow University of Health Sciences $(\mathrm{N}=900)$ were approached. However, those who were absent on the day of data collection and those who refused to participate in this study were excluded. Any kind of missing information in the questionnaire collected by the participant also deemed that participant as excluded. The questionnaire was distributed one time only by the first author. Only 750 questionnaires in total could be distributed as per their presence and verbal consent. Questionnaire to undergraduate students were distributed in the lecture halls while house officers and trainees were approached in their respective outpatient departments during their clinical rotations. Immediately next day the questionnaires were collected back from all of them. Only 480 completely filled questionnaires were included in the study which comprised of 229 from undergraduates and 251 from graduates as per the purpose of identifying differences in the responses of the two groups.

The questionnaire used in this study was adapted from a similar previous study conducted by Eman Arnout et al. ${ }^{4,5}$
It consisted of four sections the first section categorized the samples demographically according to age, gender and qualification. The next section comprised of questions based on the knowledge of radiation hazards with multiple choice answers. Third set of questions again with multiple choice answers targeted to assess the attitude of dental students towards the technique of dental radiography. The final section of multiple choice questions was aimed at evaluating the extent of protection protocols of radiology followed by the participants.

The collected data was entered processed and analyzed through SPSS (version 16.0). Statistical significance was evaluated by the application of Pearson Chi-square test. Mean and standard deviation was calculated on the basis of age and gender of the participants and frequency percentage was calculated for the overall categorical variables. A $p$ value of $<0.05$ was considered significant.

\section{RESULT}

The study participants included a total of 480 subjects consisting of 229 undergraduates with age ranging between 18 years to $25 y$ years and 251 graduates with age ranging from 24 years to 40years; among the two groups 115 were males and 365 females. Tables 1.1-1.3 signify the difference in

Table 1.1 Knowledge based questions given to participants and their responses

\begin{tabular}{|c|c|c|c|c|}
\hline Study Variable & & $\begin{array}{l}\text { Undergraduates } \\
n=229\end{array}$ & $\begin{array}{l}\text { Graduates } \\
n=251\end{array}$ & $\begin{array}{l}\mathrm{p}- \\
\text { value }\end{array}$ \\
\hline \multirow[t]{3}{*}{ Are dental x-rays harmful? } & Yes & $63.7 \%$ & $78.8 \%$ & \multirow[t]{3}{*}{0.000} \\
\hline & No & $30.1 \%$ & $21.1 \%$ & \\
\hline & Don't know & $6.1 \%$ & $0 \%$ & \\
\hline \multirow{3}{*}{$\begin{array}{l}\text { Are } x \text {-rays reflected from the walls of } \\
\text { the room? }\end{array}$} & Yes & $34 \%$ & $63.7 \%$ & \multirow[t]{3}{*}{0.000} \\
\hline & No & $44.5 \%$ & $27 \%$ & \\
\hline & Don't know & $21.3 \%$ & $9.1 \%$ & \\
\hline \multirow{3}{*}{$\begin{array}{l}\text { Can you recognize the radiation } \\
\text { hazard symbol? }\end{array}$} & Yes & $54.5 \%$ & $67.3 \%$ & \multirow[t]{3}{*}{0.000} \\
\hline & No & $24.8 \%$ & $24.7 \%$ & \\
\hline & Don't know & $20.5 \%$ & $7.9 \%$ & \\
\hline \multirow{3}{*}{$\begin{array}{l}\text { Do you know about the ALARA } \\
\text { principle? }\end{array}$} & Yes & $19.2 \%$ & $64.5 \%$ & \multirow[t]{3}{*}{0.000} \\
\hline & No & $31.8 \%$ & $19.1 \%$ & \\
\hline & Don't know & $48.9 \%$ & $16.3 \%$ & \\
\hline \multirow{3}{*}{$\begin{array}{l}\text { Are you aware of the NCRP/ICRP } \\
\text { (National Council on Radiation } \\
\text { Protection and } \\
\text { measurement/International } \\
\text { Commission on Radiological } \\
\text { Protection) recommendations? }\end{array}$} & Yes & $4.3 \%$ & $18.3 \%$ & \multirow[t]{3}{*}{0.000} \\
\hline & No & $43.2 \%$ & $58.5 \%$ & \\
\hline & Don't know & $52.4 \%$ & $23.1 \%$ & \\
\hline \multirow{4}{*}{$\begin{array}{l}\text { What should be the ideal distance for } \\
\text { an operator to be standing at during } \\
\text { the performance of radiographic } \\
\text { exposure? }\end{array}$} & $\begin{array}{l}2 \text { feet and } 90^{\circ}- \\
135^{\circ}\end{array}$ & $20.5 \%$ & $11.9 \%$ & \multirow[t]{4}{*}{0.000} \\
\hline & $\begin{array}{l}4 \text { feet and } 60^{\circ}- \\
90^{\circ}\end{array}$ & $24.8 \%$ & $29.4 \%$ & \\
\hline & $\begin{array}{l}6 \text { feet and } 90^{\circ}- \\
135^{\circ}\end{array}$ & $14.8 \%$ & $45 \%$ & \\
\hline & Don't know & $39.7 \%$ & $13.5 \%$ & \\
\hline
\end{tabular}


Table 1.2 Attitude based questions given to participants and their responses

\begin{tabular}{|c|c|c|c|c|}
\hline Study Variable & & $\begin{array}{l}\text { Undergraduates } \\
\mathrm{n}=229\end{array}$ & $\begin{array}{l}\text { Graduates } \\
\mathrm{n}=251\end{array}$ & p-value \\
\hline \multirow{4}{*}{$\begin{array}{l}\text { Do you take multiple } \\
\text { radiographs for diagnostic } \\
\text { purpose? }\end{array}$} & Often & $13.1 \%$ & $14.3 \%$ & \multirow[t]{4}{*}{0.000} \\
\hline & Sometimes & $44.5 \%$ & $56.1 \%$ & \\
\hline & Rarely & $26.6 \%$ & $23.5 \%$ & \\
\hline & Never & $15.7 \%$ & $5.9 \%$ & \\
\hline \multirow{3}{*}{$\begin{array}{l}\text { What is your technique of } \\
\text { choice of endodontic } \\
\text { radiography? }\end{array}$} & Bisecting angle & $34 \%$ & $34.2 \%$ & \multirow[t]{3}{*}{0.000} \\
\hline & Paralleling & $52.4 \%$ & $64.1 \%$ & \\
\hline & Any other & $13.5 \%$ & $1.5 \%$ & \\
\hline \multirow{3}{*}{$\begin{array}{l}\text { Conventional radiography } \\
\text { requires more exposure } \\
\text { than digital radiography }\end{array}$} & Yes & $35.3 \%$ & $34.2 \%$ & \multirow[t]{3}{*}{0.000} \\
\hline & No & $10 \%$ & $64.1 \%$ & \\
\hline & Don't know & $54.5 \%$ & $1.5 \%$ & \\
\hline \multirow{3}{*}{$\begin{array}{l}\text { Are you accustomed with } \\
\text { the use of a dosimeter? }\end{array}$} & Yes & $2.6 \%$ & $14.7 \%$ & \multirow[t]{3}{*}{0.000} \\
\hline & No & $42.7 \%$ & $55.3 \%$ & \\
\hline & Don't know & $54.5 \%$ & $29.8 \%$ & \\
\hline \multirow{3}{*}{$\begin{array}{l}\text { Are dental radiographs } \\
\text { completely contraindicated } \\
\text { in pregnant patients? }\end{array}$} & Yes & $34 \%$ & $26.6 \%$ & \multirow[t]{3}{*}{0.000} \\
\hline & No & $34.9 \%$ & $69.3 \%$ & \\
\hline & Don't know & $31 \%$ & $3.9 \%$ & \\
\hline
\end{tabular}

Table 1.3 Practice based questions given to participants and their responses

\begin{tabular}{|c|c|c|c|c|}
\hline Study Variable & & $\begin{array}{l}\text { Undergraduates } \\
\mathrm{n}=229\end{array}$ & $\begin{array}{l}\text { Graduates } \\
\mathrm{n}=251\end{array}$ & p-value \\
\hline \multirow{3}{*}{$\begin{array}{l}\text { During exposure do you } \\
\text { hold the film with your } \\
\text { hand? }\end{array}$} & Yes & $42.7 \%$ & $45.4 \%$ & \multirow[t]{3}{*}{0.000} \\
\hline & No & $40.1 \%$ & $51.3 \%$ & \\
\hline & Don't know & $17 \%$ & $3.1 \%$ & \\
\hline \multirow{3}{*}{$\begin{array}{l}\text { Is it part of your routine } \\
\text { practice to ask the patient } \\
\text { to hold the film with their } \\
\text { hand during exposure? }\end{array}$} & Yes & $34 \%$ & $27.8 \%$ & \multirow[t]{3}{*}{0.000} \\
\hline & No & $42.3 \%$ & $66.5 \%$ & \\
\hline & Don't know & $23.5 \%$ & $5.5 \%$ & \\
\hline \multirow{3}{*}{$\begin{array}{l}\text { Do you regularly use } \mathrm{X} \text { - } \\
\text { film holding devices for } \\
\text { intra-oral radiography? }\end{array}$} & Yes & $13.5 \%$ & $39.8 \%$ & \multirow[t]{3}{*}{0.000} \\
\hline & No & $44.5 \%$ & $53.7 \%$ & \\
\hline & Don't know & $41.9 \%$ & $6.3 \%$ & \\
\hline \multirow{3}{*}{$\begin{array}{l}\text { Is the use of lead apron a } \\
\text { regular part of your dental } \\
\text { radiological practice? }\end{array}$} & Yes & $10 \%$ & $33.8 \%$ & \multirow[t]{3}{*}{0.000} \\
\hline & No & $51.9 \%$ & $61.3 \%$ & \\
\hline & Don't know & $37.9 \%$ & $4.7 \%$ & \\
\hline \multirow{3}{*}{$\begin{array}{l}\text { Do you advise dental } \mathrm{x}- \\
\text { rays to pregnant patients? }\end{array}$} & Yes & $12.2 \%$ & $20.3 \%$ & \multirow[t]{3}{*}{0.000} \\
\hline & No & $70.3 \%$ & $76.4 \%$ & \\
\hline & Don't know & $17.4 \%$ & $3.1 \%$ & \\
\hline
\end{tabular}

responses to questions on knowledge, attitude and practice of dental radiography between the two groups along with statistical values. A significant difference can be appreciated between the values of results obtained among undergraduates and graduates.

\section{DISCUSSION}

Radiation exposure may be associated with causing harm to the living cells and DNA that might result in shortening human life span this has led medical practitioners to the development of unorthodox specialized and specific radiation techniques like cone beam computed tomography (CBCT) and magnetic resonance imaging (MRI) etc. ${ }^{2,7}$ Dental radiography is not usually associated with the same kind of hazardous effects it still is essential to monitor and control its stochastic effects. This may be achieved by possessing enough knowledge of the radiation biology and adhering to the protection protocols recommended by NCRP/ICRP. 2,6

The result of the present study shows the recognition of dental x-rays as being harmful with a positive response from significant number of participants, undergraduates and graduates alike. But on elaboration of x-rays being reflected from walls graduates came up with far better response than undergraduates indicating the difference in experience. This comes out as a better response compared to the study 
published in January 2017 conducted in India in which a very non-significant number of graduates responded positively. ${ }^{2}$ This may pertain to the fact that the current study included graduates with far greater years of experience not just interns but postgraduate trainees and participants with private practices as well. Almost half the sample size of participants claimed to recognize the radiation hazard symbol, far less in comparison to the result of study conducted in an Indian institution. ${ }^{6}$ It is worth mentioning though that there is significant difference in the sample size of both the studies also a greater proportion of graduates in the current study. NCRP/ICRP introduced the ALARA principle 'As Low As Reasonably Achievable' in order to monitor the amount of radiation exposure along with its own recommended radiation protection guidelines but the overall response suggested negligence in this field. ${ }^{4,5}$ There was lack of knowledge about the ALARA principle and even lesser participants from both groups were aware of the NCRP/ICRP recommendations. Similar results were reported by a study on dental students in India as well. ${ }^{1}$ Astonishingly quite nonsignificant number of participants possess the correct knowledge of the position distance rule. This rule helps in reducing the intensity and scattering effects of radiation. ${ }^{1,3}$ A study in Egypt reported better results but with far smaller sample size which consisted of very small number of undergraduate participants in comparison to the current study. ${ }^{4}$

About the attitude of practitioners towards dental x-ray techniques a mixed response was observed on being asked about the advice of multiple radiographs for diagnostic purpose. Again an average response was recorded regarding endodontic radiography. Surprisingly small number of participants agreed that conventional radiography requires more exposure than digital radiography. An Indian study reported quite a positive outcome but the participants had only recently been posted in the department of radiology while another institutional study also had comparatively better positive feedback. ${ }^{1,6} \mathrm{~A}$ dosimeter is a self-monitoring device used to measure the amount of radiation that a person is exposed to over a course of time. It is extremely useful for professionals involved in everyday radiography. ${ }^{1,5}$ The study revealed that a very non- significant number of undergraduates and graduates are aware of the use of dosimeters in dental radiography. Difference in attitude can be assessed with less than average response from undergraduates and a significant positive response from graduates in agreeing that dental radiography is not completely contraindicated in pregnant patients but to be advised with extreme caution and special precautions. A similar outcome was revealed in a study conducted on Egyptian students. ${ }^{4}$ Direct contact of dental professionals and patients with the radiation source during exposure should be minimized as much as possible. Regarding the everyday dental radiography practice a low to average outcome was revealed by the participants about their $\mathrm{x}$-film holding techniques. Of even lower significance is the number of participants in both groups admitting to the use of $\mathrm{x}$-film holding devices during exposure. Lead serves as one of the best radiation barriers leading to its use in lead aprons to reduce the harmful effects of exposure for professionals and patients alike. ${ }^{1,7}$ This study reveals that a very non-significant proportion of participants use lead aprons in their routine dental radiological practice. In comparison to quite a better response reported by studies conducted in India and Saudi Arabia we might take in consideration the unavailability of protective equipment to the participants of the current study. ${ }^{1,5}$ Quite a significant positive response was recorded from both groups about not advising $\mathrm{x}$-rays to pregnant patients as a precautionary measure.

More studies should be conducted at other study settings not only on dental students but on practitioners as well to evaluate dental radiography practices being conducted by dentists in our region. Dental education curriculum should be investigated for what value is given to the protection protocols and techniques of dental radiography at undergraduate and post graduate study levels. Strengths/Weaknesses/Limitations of Study: This study has a large sample size which gives us considerable amount of data for analysis and evaluation of awareness about dental radiography among dental students. Also the questionnaire used consists of precise and basic questions related to dental radiography for both undergraduate and graduate level students.

Our study was limited by the loss of a considerable amount of data due to the exclusion criteria of the study. The number of subjects in the comparative groups of undergraduates and graduates was unequal. The responses may vary depending on the learning level year or semester of an undergraduate or post graduate dental student.

\section{RECOMMENDATIONS}

Dental radiography should be an important aspect of undergraduate dental education. With due theoretical knowledge being imparted clinical practice is all the more important for the application of that knowledge and should become routine practice in teaching institutes. Continuing radiological education for graduates holds importance in refreshing their previous knowledge along with being up to date with new technology and changes in NCRP/ICRP recommendations. Seminars and workshops are the best way for graduates to share and increase their knowledge. 


\section{CONCLUSION}

The results of this study show lack of knowledge regarding the biology, hazards and practice of dental radiography among the two groups. Due consideration is required to the basic knowledge and education of radiology specially at undergraduate level while the lacking at the graduate level can be dealt with repeated short courses and workshops on the subject.

\section{CONFLICT OF INTEREST}

None declared.

\section{REFERENCES}

1. Srivastava R, Jyoti B, Jha P, Shukla A. Knowledge, attitude, perception toward radiation hazards and protection among dental undergraduate students: A study. Journal of International Oral Health. 2017; 9(2): 81 .

https://doi.org/10.4103/jioh.jioh_26_16

2. Swapna LA, Koppolu P, Takarji B, Al-Maweri SA, Velpula N, Chappidi V, et al. Knowledge on Radiation Protection \& Practice among Dental Students. Brit J Med Med Res 2017; 9 (7): 1-7

https://doi.org/10.9734/BJMMR/2017/30761
3. Tejavathi Nagaraj NS, James L, Veerabasaviah BT, Goswami RD, Balraj L. An assessment of knowledge and perception of postgraduate students and interns toward radiation protection protocols: A questionnaire-based study in dental colleges. J Med Radiol Pathol Surg 2016; 3: 5-9.

4. Arnout E. Knowledge, attitude and perception among Egyptian dental undergraduates, interns and postgraduate regard biological hazards and radiologic protection techniques: a questionnaire based cross-sectional study. Life Sci J. 2014; 11(6): 9-16.

5. Arnout E, Jafar A. Awareness of biological hazards and radiation protection techniques of dental imaging-A questionnaire based crosssectional study among Saudi dental students. J Dent Health Oral Disord Ther. 2014; 1(1): 1-7.

https://doi.org/10.15406/jdhodt.2014.01.00008

6. Prabhat M, Sudhakar S, Kumar BP. Knowledge, attitude and perception (KAP) of dental undergraduates and interns on radiographic protection-A questionnaire based cross-sectional study. J Adv Oral res. $2011 ; 2(3)$ : 45-50.

7. Hussein RE, Hashim NT, Awooda EM. Knowledge, Awareness And Practice of Sudanese Dentists Towards Oral Radiology And Protective Guidelines. IOSR J Dent Med Sci 2016;15(10):79-83. https://doi.org/10.9790/0853-1510047983 